УДК 37-056.2/.3:141.7

DOI: 10.37026/2520-6427-2019-99-3-10-12
Світлана ГРЕБІНЬ,

кандидатка філософських наук, дочентка кафедри дидактики та методик навчання природничо-математичних дисчиплін Запорізького ОІППО

\title{
СОЦІАЛЬНА ІНКЛЮЗІЯ: АСПЕКТ «ВКЛЮЧЕННЯ» ДІТЕЙ ДО СУСПІЛЬСТВА ДОРОСЛИХ
}

\begin{abstract}
У статті розглядається поняття «соиіальної інклюзї̈» в розумінні «включення до суспільства». Зміст иьього вислову можна трактувати не лише як «включення» до загальноосвітнього проиесу дітей з особливими освітніми потребами, а насамперед як «включення» до "суспільства дорослих» усіх без винятку дітей. Доводиться думка про те, що батьки не повинні перекладати свої безпосередні обов'язки шодо виховання дітей на педагогів та оточення. Представлені рекомендації з означеного питання видатного педагога XX століття А. С. Макаренка.
\end{abstract}

Ключові слова: сочіум, суспільство, інклюзія, включення, діти, батьки, дорослі, колектив.

В статье рассматривается понятие «социальной инклюзии» в смысле "включения в обшество». Содержание этого высказывания можно трактовать не только как "включение» в общеобразовательный проиесс детей с особыми образовательными потребностями, но и как «включение» в «общество взросльх» всех без исключения детей. Доказывается мнение о том, что родители не должны перекладывать свои непосредственные обязанности по воспитанию детей на педагогов и окружение. Представлены рекомендачии по указанному вопросу выдаюшегося педагога ХХ века А. С. Макаренко.

Ключевые слова: сочиум, общество, инклюзия, включение, дети, родители, взрослье, коллектив.

The article discusses the concept of "social inclusion» in the sense of "inclusion in society». "Social inclusion» in translation from English is inclusion in society. Along with the concept of "social inclusion», the term "inclusive education» is often used. It means "inclusion" of a certain category of people in the general education process. And we know that according to the new Law of Ukraine «About Education» (2017), children with special educational needs have the right to study in secondary schools near with all other children.

But they have the right to exist other points of view on the problem of social inclusion. The meaning of this concept can be viewed not only as the «inclusion» of children with special educational needs in the general educational process, but also as the «inclusion» of all our children in an adult society. This kind of social inclusion is an important aspect of the development of society at the present stage. Society needs educated citizens. The main people in shaping the child's personality are parents and teachers, and above all-parents who should not shift their parental responsibilities to teachers and other people.
A big mistake is made by those parents who are trying to «separate» their children into a «children's» society, justifying this by a lack of time. The great teacher of the twentieth century, A. S. Makarenko, wrote that such parents «have no responsibility to their children and to society». And some parents do it quite consciously for their personal comfort and convenience. "Living with children as a team»-is an important principle for raising children and the advice of Makarenko to parents. This principle is very similar to the modern «inclusion» of children in an adult society.

Key words: society, society, inclusion, inclusion, children, parents, adults, team.

Постановка проблеми. Зміна загальної освітньої стратегії держави на сучасному етапі зумовлена трансформаціями, що відбуваються впродовж останнього часу в українському суспільстві. Оновлення всіх сфер його життєдіяльності диктує і нову концепцію освіти. Традиційний підхід до навчання - надання «готових» знань - відійшов на другий план. Актуальними завданнями оновленої системи освіти сьогодні є: забезпечення конкурентоздатності української молоді на європейському ринку праці, формування компетентностей, що сприятимуть набуттю нових знань, якими можна буде послуговуватися у майбутній практичній діяльності та які будуть корисними в житті.

У сучасну систему освіти увійшли такі відносно нові для педагогіки поняття, як «праксеологія», «аксіологія», «акмеологія», «синергетика», «інклюзія» та ін. Розглянемо детальніше та спробуємо переосмислити одне із них - «соиіальна інклюзія», яке у сучасних умовах перебудови освіти набуває все більшої актуальності.

Інклюзія (inclusion) у перекладі з англійської мови означає «включення», відповідно «соціальна» походить від слова «соціум» - суспільство. Отже, дослівно це словосполучення можна розуміти як «включення до суспільства». Одночасно із поняттям «соиіальна інклюзія» вживають ще одне, близьке до нього поняття, «інклюзивне навчання», тобто «включення» певної категорії людей у загальноосвітній процес.

Відповідно до Закону України «Про освіту» (2017 р.) діти з особливими освітніми потребами мають таке саме право навчатися у закладах загальної середньої освіти, як й інші діти. Зокрема в розділі 2 (стаття 20, пункт 1) зазначається: «Заклади освіти за потреби утворюють інклюзивні та/або спеціальні групи і класи для навчання осіб з особливими освітніми потребами. У разі звернення особи з особливими освітніми потребами або іiї батьків така група або клас утворюється в обов'язковому порядку» [1]. 
Таким чином, відбувається «включення» дітей із вадами здоров'я до загального дитячого суспільства, що стало результатом змін у життєдіяльності соціуму загалом та освітньої стратегії держави зокрема.

Аналіз наукових досліджень і публікацій. Різні аспекти соціальної інклюзії та інклюзивного навчання досліджувалися як українськими, так і зарубіжними вченими. Серед вітчизняних авторів теоретико-методологічні й організаційні засади та шляхи впровадження інклюзії в роботу вивчали В. Шнайдер та Н. Лалак; проблеми інклюзивного навчання характеризували Д. Величко, О. Дікова-Фаворська, С. Сфімова, А. Колупаєва, І. Кузава, 3. Удич; європейський досвід щодо питань інклюзивної освіти досліджували Г. Давиденко та Т. Перегудова; понятійну термінологію інклюзивної освіти обгрунтувала I. Калініченко; питаннями інтеграції та інклюзії дітей 3 особливими освітніми потребами, їх оцінюванням займалися Н. Гаврилова та Т. Сак, а питаннями інклюзивної освіти в умовах професійно-технічного навчального закладу - О. Пащенко.

Таким чином, безсумнівно, всі вищеозначені аспекти є важливими, своєчасно висвітленими та посіли належне місце серед наявних наукових досліджень. Однак, на нашу думку, мають право на існування й інші точки зору щодо висвітлення проблеми соціальної інклюзії, зокрема включення дітей до «суспільства дорослих», що ми і спробуємо висвітлити в означеній статті.

Мета статті - розглянути один із нових аспектів сучасної педагогіки - «включення дітей до суспільства дорослих»; охарактеризувати його значення в сучасних умовах.

Виклад основного матеріалу. Дитинство - соціокультурний феномен, що є продуктом суспільства, в яке воно інтегрується. «Дитинство не має самостійної властивості до самостабілізації та самоорганізації, без відповідної корекції та підтримки не може пристосуватися та адаптуватися до сформованих $\mathrm{i}$ динамічно мінливих умов його зовнішнього оточення (підтримки сім'ї, низки інших соціальних інститутів» [3, с. 174]. Основні траєкторії дитячої поведінки (родинні, правові, гендерні та інші) починають закладатися в родині в дошкільному віці, а отже, якою стане дитина насамперед залежать саме від сім'ї. Слід вказати і на парадоксальні протиріччя між суспільною свідомістю щодо соціальних практик, які стосуються навчання і виховання дітей, та сучасним статусом дитинства. В умовах сучасного українського суспільства оновлюються традиційні моделі соціалізації дітей. Як відомо, в українській традиції початковий етап у житті дитини передбачав тісний контакт із батьками та іншими членами родини, однак сьогодні ситуація дещо змінилася - суспільство воліє проявляти любов до дитини за допомогою економічних витрат та різноманітних інноваційних технічних приладів, наприклад, таких як, штучні суміші для годування, «ходунки», «памперси», «електронні няні» тощо. «Живий» контакт дорослих із дитиною невпинно скорочується. Батьки в суспільстві постмодерну, не додаючи дітям належної уваги, виправдовують це нестачею часу на виховання зайнятістю на роботі та нагальними справами. Вони з радістю готові «відкупитися» від дитини подарунками (мобільним телефоном, комп'ютером, планшетом, дорогими іграшками), переклавши всю відповідальність за виховання і розвиток на няню, вихователя, вчителя, гувернера та ін. «Зникає етнокультурна своєрідність раннього догляду за дітьми. В суспільстві поступово поширюється думка про те, що професійні «замінники батьків» можуть непогано впоратися з батьківськими функціями» [3, с. 177].

Однак, переосмислюючи та аналізуючи педагогічний спадок минулого, помічаємо, що схожі відносини між батьками і дітьми існували в родинах і в минулому столітті. Так, описуючи типи батьківського авторитету в «Лекціях про виховання дітей», видатний педагог XX ст. А. С. Макаренко писав: «Бувають і такі матері: у них своє життя, свої інтереси, свої думки. Діти знаходяться у розпорядженні бабусі або навіть домогосподарки. Нічого і казати, що такий авторитет не приносить ніякої користі...» [4, с. 7]. Педагог закликав батьків щиро цікавитися життям дитини, іiї оточенням, вчасно допомагати розібратися в складних життєвих ситуаціях, зупиняти та спрямовувати дитину, але не створювати «тепличних» умов для неї, не огороджувати від різноманітних впливів: «...вашу батьківську справу ви повинні виконувати якнайкраще, і в цьому полягають коріння вашого авторитету. Передусім ви повинні знати, чим живе, цікавиться, що любить і що не любить, чого хоче і чого не хоче ваша дитина. Ви повинні знати, 3 ким вона дружить, із ким і в що грається, що читає, як сприймає прочитане. Якщо вона вчиться в школі, вам має бути відомо, як вона ставиться до школи та до вчителів, з якими труднощами стикається, як поводиться в класі. Це все ви повинні знати завжди, з найменших років вашої дитини. Ви не повинні несподівано дізнаватися про різні неприємності та конфлікти, ви повинні їх передбачати і попереджати» [4, с. 10]. Саме так Антон Семенович намагався донести до батьків думку, яка червоною лінією проходить крізь усю його творчість: родина - ие єдиний колектив, а дитина потребує батьківської уваги та підтримки завжди.

«У житті кожної дитини буває чимало випадків, коли вона потребує поради та допомоги, коли не знає, як правильно вчинити. Можливо, вона не попросить вас про допомогу, адже не вміє цього робити, ви самі повинні допомогти їй» [4, с. 10]. Про яку допомогу сьогодні можна стверджувати, якщо чимало сучасних батьків більшість часу приділяють не вихованню власних дітей, а роботі та особистим справам!?

Наріжним каменем у вихованні сучасних дітей є також відверта недбалість деяких батьків, які усвідомлено «витісняють» своїх дітей зі «свого світу», «свого суспільства», відносять до іншого, «дитячого», суспільства. Як приклад - випадок із власного життя, свідком якого я стала. Два трирічних хлопчики, гуляючи без батьків влітку у дворі п'ятиповерхового будинку, намагалися зацікавити себе чимось, знайти для себе будь-яке заняття. Батьки ж у цей час спокійно відпочивали у власних квартирах, незважаючи на дітей та не цікавлячись, де і з ким вони граються. Отже, діти залишились абсолютно «виключеними» із суспільства дорослих членів своїх родин упродовж тривалого часу, їх поведінку коригувала лише «вулиця», тобто випадкові перехожі, які час від часу робили їм зауваження, адже діти поводилися неналежно розгойдували за хвоста кошеня, яке впіймали у дворі, кидалися землею з клумби та камінням, грюкали палицями по дитячій металевій гірці тощо. Під час таких «розваг» батьків, які б мали пояснити дітям, що так поводитися неприпустимо, не було поряд, адже вони у цей час займалися своїми, «дорослими», справами. 
По суті, діти були віддані на «виховання» чужим людям. Цей випадок - приклад того, як не потрібно виховувати дітей, адже і сьогодні є чимало батьків, які свідомо усуваються від цього важливого обов'язку заради власного комфорту та зручностей. Вони «виключають» своїх дітей зі свого «дорослого» суспільства, ненав' язливо «відтіснивши» у суспільство «дитяче». Чому так відбувається? Чому в деяких батьків такий низький рівень відповідальності за найдорожче, що вони мають у цьому житті?

А. С. Макаренко у своїх працях частково дає відповідь на ці та багато інших запитань, що стосуються виховання дітей, зокрема він пише, що відмовки про нестачу часу вигадали батьки-невдахи, і що для прояву батьківської уваги потрібно «уміло використовувати свій час» $[4$, с. 5]. Педагог акцентує увагу на тому, що батьківський обов'язок перед дитиною - це «особлива форма обов'язку перед суспільством», суспільству потрібні гарно виховані громадяни. А щодо батьків, в яких не вистачає часу, педагог зауважує: «Виховання вимагає набагато більше душі, неослабної уваги, все більш зростаючого почуття відповідальності, а не часу. I чим старша дитина, тим менше вона потребує часу, але тим більша за неї відповідальність...» [5, с. 1]. Варто пам'ятати також слова Антона Семеновича про те, що батьківська любов вимірюється не кількістю подарунків, а відповідальністю перед дитиною та суспільством. А щодо виправдань батьків про нестачу часу для виховання, то думка педагога однозначна: «... усі ці виправдання нічого не варті - не часу мало в таких батьків, у них відсутнє почуття відповідальності перед власною дитиною та перед суспільством» $[5$, с. 1$]$.

Насамкінець хочемо зауважити, що головний принцип педагогічної системи видатного педагога «живіть із дітьми одним життям, одним колективом...» [2, с. 1], тобто будьте 3 ними єдиним цілим, впустіть їх у своє «доросле суспільство» - i досі залишається надзвичайно актуальним.

Висновки. Отже, поняття «соціальна інклюзія» слід розуміти не лише як «включення» дітей 3 особливими потребами у загальноосвітній процес, а також і як «включення» всіх без винятку дітей до «суспільства дорослих». Цей різновид соціальної інклюзії $\epsilon$ на сучасному етапі важливим аспектом розвитку соціуму, адже діти у будь-якому віці надзвичайно потребують уваги дорослих, насамперед батьків, які не повинні перекладати свої обов'язки на педагогів та оточення, а усвідомити, що саме від них залежить, якою їхня дитина увійде у доросле життя.

\section{СПИСОК ВИКОРИСТАНОЇ ЛІТЕРАТУРИ}

1. Закон України «Про освіту» від 05.09.2017 № 2145-VII [Електронний ресурс]. URL: https:// zakon.rada.gov.ua/laws/show/2145-19 (дата звернення: 20.05.2019).

2. Косинцева Д. Шесть принципов, которым советский педагог Макаренко может научить современную маму [Электронный ресурс] / Д. Косинцева // Матроні.RU - консервативный женский журнал. - 2018. URL: http://www.matrony.ru/6-printsipov-kotoryimsovetskiy-pedagog-makarenko-mozhet-nauchit-sovre mennuyu-mamu/ (дата звернення: 15.05.2019).

3. Майорова-Щеглова С. Н. Трансформации детства в начале XXI века: к уточнению концепции социального конструирования детства [Электронный ресурс] / С. Н. Майорова-Щеглова // Сайт «CYBERLENINKA».-2014.URL:https://cyberleninka. $\mathrm{ru} /$ article/n/transformatsii-detstva-v-nachale-xxi-v-kutochneniyu-kontseptsii-sotsialnogo-konstruirovaniyadetstva-1 (дата звернення: 16.05.2019).

4. Макаренко А. С. Лекции о воспитании детей [Электронный ресурс] / A. C. Макаренко. URL: www.makarenko.edu.ru/files/lekcii_o_vospitanii.doc (дата звернення: 20.05.2019).

5. Макаренко А. С. Советы родителям [Электронный ресурс] / А. С. Макаренко // Избранные произведения : в 3 т. - К. : Радянська школа, 1985. - Т. 3. - 592 с. URL: http://az.lib.ru/m/makarenko_a_s/text_1937_sovety_ roditelyam.shtml (дата звернення: $\overline{20} .05 .2 \overline{0} 19)$.

Дата надходження до редакиії: 18.06.2019 р.
УДК 37.091.4:37.091.214.18

DOI: 10.37026/2520-6427-2019-99-3-12-15

\author{
Алла КОРОЛЮК, \\ старша викладачка кафедри \\ природничо-математичної освіти \\ Рівненського ОІППО
}

\section{ПРО МІЖПРЕДМЕТНІ ЗВ'ЯЗКИ У ТВОРЧОМУ ДОРОБКУ В. О. СУХОМЛИНСЬКОГО}

У статті основна увага приділяється питанню реалізації міжпредметних зв'язків математики з іншими шкільними дисциплінами. Доведено необхідність комплексного розв'язання проблеми. Проаналізовано педагогічні ідеї В. О. Сухомлинського щчодо міжпредметних зв'язків та їх ролі у формуванні изілісної картини світу.

Ключові слова: інтеграція навчання, математика, міжпредметні зв'язки, педагогічна спадщчина В. О. Сухомлинського. 